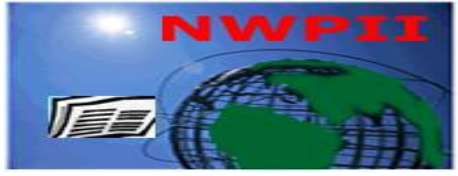

\title{
Some Haematological Parameters of Human Immunodeficiency Virus Subjects Co-infected with Tuberculosis in Osun State, Nigeria.
}

\author{
${ }^{1}$ ADEYEMI, O. A., ${ }^{2}$ Okungbowa, M. A. O., ${ }^{3}$ Alade, D. T., ${ }^{4}$ Ajileye A. B. \\ ${ }^{1}$ Department of Medical Laboratory Science, Achievers University, Owo, Ondo State. \\ ${ }^{2}$ Department of Medical Laboratory Science, School of Basic Medical Sciences, University of Benin, Benin City, Edo \\ State. \\ ${ }^{3}$ Department of Medical Laboratory Services, Ladoke Akintola University of Technology Teaching Hospital, Osogbo, \\ Osun State. \\ ${ }^{4}$ Department of Biomedical Laboratory Science, College of Medicine, University of Ibadan. \\ "Corresponding Author \\ AJILEYE Ayodeji Blessing \\ Department of Biomedical Laboratory Science, \\ College of Medicine, \\ University of Ibadan \\ Nigeria \\ Email: ayobless05@gmail.com ab.ajileye@ui.edu.ng \\ Tel: +2348030445624
}

Received:16 August 2020; $\mid$ Revised:21 August 2020; $\mid$ Accepted:07 December 2020

\section{Abstract}

Introduction: HIV-infected persons are at markedly increased risk for primary or reactivation tuberculosis. Tuberculosis complicates HIV infection and is associated with a more rapid clinical decline, changes in haematological parameters, and as the infection progresses these changes become more prominent.

Aim: The aim of this study was to assess the haematological parameters (prothrombin time, partial thromboplastin with kaolin, platelet count and full blood count) among patients living with HIV, co-infected with TB

Method: One hundred and sixteen subjects were recruited and divided into 3 age groups of 21-30 years, 31-40 years and 41-50 years, they were further divided based on settlement, religion, sex, occupation and educational status. Haematological parameters were assayed using the automated KX-21, SYSMEX. Standard procedures were used to assay for prothrombin time (PT) and partial thromboplastin time with kaolin (PTTK) studies.

Results and Discussion: The platelet count was not statistically significant when comparing the test subjects to control subjects $(\mathrm{p}=0.142)$. Prothrombin time $(\mathrm{PT})$ and partial thromboplastin time with Kaolin (PTTK) of test group were significantly prolonged than that of the control group $(\mathrm{P}<0.05)$. Total white blood cell count (TWBC), $\mathrm{CD}_{4}$ cell count, lymphocyte count and monocyte count were signficantly reduced when comparing the test group to control group $(\mathrm{P}<0.05)$. Red blood cell count, haemoglobin concentration, and packed cell volume $(\mathrm{PCV})$ also showed a significant reduction $(\mathrm{P}<0.05) . \mathrm{MCV}(\mathrm{P}<0.05)$ and $\mathrm{MCHC}$ 
$(p=0.027)$ were observed to be statistically higher in urban settlers. There was a significant increase in the PTTK, MCHC and neutrophil count among females when compared with males $(\mathrm{p}<0.05)$. Whereas platelet count, $\mathrm{CD}_{4}$ cell count, $\mathrm{MCH}, \mathrm{PCV}, \mathrm{Hb}$ concentration, $\mathrm{RBC}$ count, $\mathrm{MCV}$, lymphocyte count, monocyte count and eosinophil were all significantly raised in male subjects $(\mathrm{P}<0.05)$. There was a significant increase in the Total WBC in males than in females $(\mathrm{P}=0.047)$. This study also observed a correlation between platelet count, TWBC and $\mathrm{CD}_{4}$ cell count. Subjects that are of the ages of 31-40 years group had the highest prevalence rate of HIV-TB co-infection. Subjects in the rural areas also had a higher prevalence rate of HIVTB coinfection. PT and PTTK were prolonged in TB and HIV co-infected subjects.

Conclusion: Therefore $\mathrm{CD}_{4}$, TWBC, PT and PTTK, can be used to monitor how HIV co-infected with TB subjects are responding to treatment.

Keywords: Tuberculosis, Haematological, Platelet, Prothrombin, Prevalence

\section{Introduction}

Tuberculosis (TB) has been closely associated with human immunodeficiency virus (HIV) since the emergence of AIDS (acquired immune deficiency syndrome), its most common opportunistic infection affecting HIV-seropositive individuals and the most common cause of death in AIDS patients ${ }^{[1]}$. The worldwide prevalence rate of HIV infection has directly impacted on the incidence of TB ${ }^{[2]}$. HIV-related TB is treatable and preventable, although the incidence continues to increase in developing nations where HIV infection and TB are endemic and resources are limited.

Interactions between HIV and TB medications, overlapping medication toxicities, and immune reconstitution inflammatory syndrome (IRIS) complicate the co-treatment of HIV. Also, HIV infection causes a progressive decline in cellmediated immunity, thereby altering the pathogenesis of $\mathrm{TB}$, which greatly increase the risk of the disease from TB in HIV-co-infected individuals to more frequent extrapulmonary involvement, atypical radiographic manifestations, and paucibacillary disease, which can impede timely diagnosis.

HIV-infected persons are at markedly increased risk for primary or reactivation tuberculosis [3,4] and for second episodes of tuberculosis from exogenous re-infection [5]. Susceptibility to tuberculosis is related to the pattern of cytokines produced by $\mathrm{T}$ lymphocytes. $\mathrm{T} 1$ lymphocytes, which produce interferon- $\gamma$, are central to antimycobacterial immune defenses, and fatal mycobacterial disease develops in children who lack the interferon- $\gamma$ receptor ${ }^{[6]}$. In contrast to
T1 lymphocytes, T2 lymphocytes, which produce interleukin-4 and interleukin-10, do not contribute to anti-mycobacterial immunity ${ }^{[7]}$.

Haematological assessment include red blood cells, white blood cells (WBC), mean corpuscular volume (MCV), mean corpuscular haemoglobin $(\mathrm{MCH})$ and mean corpuscular haemoglobin concentration (MCHC). Red blood cells (erythrocytes) serve as a carrier of haemoglobin, which is involved in the transport of oxygen and carbon dioxide in the body ${ }^{[8]}$. Thus, a reduced red blood cell count implies a reduction in the level of oxygen that would be carried to the tissues as well as the level of carbon dioxide returned to the lungs [8].

Leucocyte function to fight infections, defend the body by phagocytosis against invasion by foreign organisms and to produce or at least transport and distribute antibodies in immune response. Thus, persons with low white blood cells are exposed to high risk of disease infection, while those with high counts are capable of generating antibodies in the process of phagocytosis and have high degree of resistance to diseases ${ }^{[9]}$ and enhance adaptability to local environmental and disease prevalent conditions ${ }^{[10]}$.

Thrombocytes are implicated in blood clotting. Low platelet concentration suggests that the process of clot-formation (blood clotting) will be prolonged resulting in excessive loss of blood in the case of injury.

Red blood cell indices such as mean corpuscular haemoglobin are major indices for evaluating circulatory erythrocytes, and are significant in the diagnosis of anaemia and also serve as useful indices of the haematopoiesis ${ }^{[11]}$. 
Mean corpuscular haemoglobin and mean corpuscular haemoglobin concentration indicate blood level conditions. A low level is an indication of anaemia ${ }^{[12,13]}$.

Human immunodeficiency virus (HIV) and its subtypes are retroviruses, which belongs to a large family of ribonucleic acid (RNA) lentiviruses that are characterized by association with diseases of immunosuppression or central nervous system involvement and with long incubation periods following infection before manifestations of illness become apparent ${ }^{[14,15]}$, and they are the main etiologic agents of AIDS.

The pathogenesis of HIV infection is a function of; the virus life cycle, host cellular environment and quantity of viruses in the infected individual. After entering the body, the viral particle is attracted to a cell with the appropriate $\mathrm{CD}_{4}$ receptor molecules where it attaches by fusion to a susceptible cell membrane or by endocytosis and then enters the cell ${ }^{[15]}$. The possibility of infection is a function of both the number of infective HIV virions in the body fluid which contacts the host as well as the number of cells available at the site of contact that have appropriate $\mathrm{CD}_{4}$ receptors ${ }^{[16]}$.

The pathogenesis of HIV begins with gp120 binding to $\mathrm{CD}_{4}$ receptor, which induces a conformational change in gp120, exposing coreceptor binding sites. The V3 loop region of gp120 determines whether the host cell CCR5 or CXCR4 chemokine co-receptor will be engaged ${ }^{[17]}$. After the chemokine co-receptor is engaged, the gp41 on the HIV surface undergoes a conformational change.

In primary infection of HIV-1, patients may be asymptomatic though sometimes the disease is selflimiting. Within the incubation period of about 6 weeks, patients can present with a mononucleosis like syndrome, which is characterized by fever, cough, painful swallowing, myalgia, arthralgia, diarrhoea as well as maculopapular rash and lymphadenopathy ${ }^{[18]}$. HIV is known to be associated with a wide range of immunological and haematological changes. The immunological changes include depletion in $\mathrm{CD}_{4}{ }^{+} \mathrm{T}$ cell, cytokine dysregulation and immune dysfunction.

The dominant immunologic feature of HIV infection is progressive depletion of the helper $\mathrm{T}$ cell $\left(\mathrm{CD}_{4}{ }^{+} \mathrm{T}\right.$-cell), which reverses the normal $\mathrm{CD}_{4}$ :
$\mathrm{CD}_{8}$ ratio and subsequently lead to immunodeficiency. $\mathrm{CD}_{4}{ }^{+}$T-cells interact with antigen presenting cells (APCs), B cells, cytotoxic $\mathrm{T}$-cells $\left(\mathrm{CD}_{8}{ }^{+} \mathrm{T}\right.$-cells $)$ as well as natural killer cells. Haematological abnormalities are common complications of HIV infection. These abnormalities increase as the disease progresses $[19$, $20,21 \& 22]$. Since HIV infection is primarily a disease of the haemopoietic system, the abnormalities commonly associated are anaemia, leucopenia, thrombocytopenia and thrombosis. This is probably due to the direct effects of the virus on bone marrow, suppression of bone marrow by secondary infections, neoplasms causing ineffective haematopoiesis, nutritional deficiencies or side effects of the drugs used ${ }^{[20]}$.

Anaemia is one of the commonest findings seen in TB patients and considered to be responsible for poor prognosis ${ }^{[23]}$. Most commonly seen anaemia is iron deficiency anaemia that decreases hosts capacity in defending against foreign antigen resulting in impaired immune response ${ }^{[24]}$. The first line of defence against any foreign organism is innate immunity characterised by phagocytosis mediated by neutrophils and macrophages.

Tuberculosis is characterised by granuloma formation hence neutrophils play a vital role in its formation. Release of tumour necrosis factor alpha (TNF- a ) from polymorphs efficiently kills the mycobacterium ${ }^{[25]}$. Platelet count also has a significant role in immune functions and thrombocytosis is generally seen in chronic inflammation stated as 'reactive thrombocytosis' ${ }^{[26]}$.

\section{Materials and Method}

Study Area:

This study was carried out in Ladoke Akintola University Teaching Hospital Osogbo, Osun State; State Specialist Hospital Asubiaro Osogbo, Osun State; State Hospital, Ikirun, Osun State and State Hospital, Ede, Osun State, Nigeria.

Ethical Approval:

Permission for this study was sought and obtained from the Ethics and Research Committee, with the Ref No OSHREC/PRS/569T/107, Ministry of Health, Osun State, Nigeria.

Inclusion Criteria: 
Subjects that fulfilled the following criteria were included in this study:-

1.Subject for this study included both males and females HIV Positive co-infected with Tuberculosis.

2.Apparently healthy males and females subjects who are HIV $1 \& 2$ negative and are AFB negative are recruited for control. study.

3.Those that consented to participate in the

Exclusion Criteria:

Subjects with the following criteria were excluded from this study:

1.Male and female HIV positive persons coinfected with tuberculosis on HAART

2.Male and female subjects who are HIV positive but are not infected with Tuberculosis

3.Male and female subjects who are AFB positive but are HIV $1 \& 2$ negative

4.Subjects that refused participation

Sample Collection:

About $7 \mathrm{ml}$ of blood samples were collected with a sterile syringe from each of the subjects, of which $4 \mathrm{ml}$ was transferred into EDTA container for the analysis of platelet count, full blood count and $\mathrm{CD}_{4} \mathrm{~T}$ cell count. The remaining $3 \mathrm{ml}$ of the blood sample was transferred into a plastic tube containing $1 \mathrm{ml}$ of aqueous tri-sodium citrate without delay for prothrombin time test (PT) and partial thromboplastin time with kaolin (PTTK). The sample to be used for the analysis of PT and PTTK was centrifuged at $1200 \mathrm{~g}$ for 15 minutes. The plasma was transferred into a plain plastic tube and kept frozen for analysis.

Sample Size:

The sample size (N) was calculated using prevalence from previous studies done on the prevalence of HIV-TB co-infection in sub Saharan which was $3.4 \%{ }^{[27]}$. The sample size for this study will be obtained using the formula below ${ }^{[28]}$.

$$
\begin{aligned}
& \mathrm{N}=\frac{\mathrm{Z}^{2} \mathrm{P}(1-\mathrm{P})}{\mathrm{D}^{2}} \\
& \mathrm{~N}=\text { required sample size } \\
& \mathrm{Z}=\text { confidence level at } 95 \% \text { (standard value of }
\end{aligned}
$$
1.96)

$\mathrm{P}=$ estimated prevalence of HIV-TB coinfection in Africa (3.4\%) $0.05)$

$\mathrm{D}=$ margin of error at $5 \%($ standard value $=$

$$
\begin{aligned}
& \mathrm{N}=\underline{1.96^{2} \mathrm{X} 0.034(1-0.034)} \\
& 0.05^{2} \\
& =\underline{3.8416 \times 0.034(0.966)} \\
& 0.0025
\end{aligned}
$$

Due to the number of test subjects encountered in the field, a total number of 116 test subjects were used and 46 controls were used.

Laboratory Analysis:

Full blood count

Full blood count was carried out on both the blood samples of the test group and that of the control group using an automated machine called KX-21, Sysmex, 2006.

Prothrombin time (PT) test:

Test Procedure for PT

$0.25 \mathrm{ml}$ of the thromboplastin/calcium reagent was pipetted into a small glass tube. The tube was placed in a $37^{\circ} \mathrm{C}$ water bath for $1-2$ minutes.

Using a calibrated capillary or delivery pipette, $50 \mu \mathrm{l}(0.05 \mathrm{ml})$ of capillary plasma was added, mixed, and a stop watch was used to time for clot formation.

The tube was held in the water bath and the mixture tilted back and forth looking for clot formation. When a clot was formed, the stop-watch was stopped and the time was recorded in seconds.

Estimation of PTTK:

Method using Kaolin/Platelet substitute mixture

$0.2 \mathrm{ml}$ of well-mixed kaolin/platelet substitute was pipette into a small glass tube.

$0.1 \mathrm{ml}$ of plasma was added, mixed, and incubate at $37{ }^{\circ} \mathrm{C}$ for exactly 2 minutes (tilting the tube at intervals).

$0.1 \mathrm{ml} 0.025 \mathrm{~mol} / 1$ calcium chloride was added, mixed and the stop-watch started.

The tube was held in the water bath and tilted the mixture back and forth, looking for clot formation.

When a clot forms, the stop-watch was stopped and the time recorded.

$\mathrm{CD}_{4}$ Cell Count:

Procedure:

1.20 microliter of $\mathrm{CD}_{4}$ monoclonal antibody was introduced into a rohren test tube

2.20 microliter of well mixed whole blood collected within 6hrs was added 
3.It was mixed and incubated in dark for 15 minutes at room temperature

4.800 microliter of $\mathrm{CD}_{4}$ buffer was added, mixed and read on the cyflow

5.The prepared sample was plugged to the port of the cyflow and allowed for acquision and data analysis. The cyflow starts from pre-run, run, count $\&$ stop. The cyflow counts a known volume of the sample and stops.

The cyflow operation is a true volumetric absolute counting. It counts only $0.2 \mathrm{mls}$ of the prepared sample. For $\mathrm{CD}_{4} \mathrm{~T}$-lymphocyte absolute count, the important value is the count $/ \mathrm{ml}$ of blood obtained.
Results

The result was calculated as follows:

Cells $/$ microliter $=\mathrm{n} \times$ Dil. factor 1000

Where $\mathrm{n}=$ count $/ \mathrm{ml}$

Dilution factor $=42$.

\section{Statistical Analysis}

Statistical analysis for Social Sciences (SPSS) version 24 was the statistical package used in analyzing all data obtained. Student T test, Pearson Chi-Square was used to compare the means of the different analytes at $\mathrm{P}<0.05$ statistical significance.

\section{Results}

Table 1: Demographic information of the test group (HIV co-infected with tuberculosis)

\begin{tabular}{|c|c|}
\hline Age group & Frequency (\%) \\
\hline $21-30 y r s$ & $10(6.2)$ \\
\hline $31-40 y r s$ & $100(61.7)$ \\
\hline $41-50 y r s$ & $52(32.1)$ \\
\hline Total & $162(100)$ \\
\hline \multicolumn{2}{|l|}{ Sex } \\
\hline Male & $59(36.5)$ \\
\hline Female & $103(63.5)$ \\
\hline Total & $162(100)$ \\
\hline \multicolumn{2}{|l|}{ Religion } \\
\hline Christianity & $33(20.4)$ \\
\hline Islam & $129(79.6)$ \\
\hline Total & $162(100)$ \\
\hline \multicolumn{2}{|l|}{ Occupation } \\
\hline Trader & $70(43.2)$ \\
\hline Artisan & $55(34.0)$ \\
\hline Unemployed & $37(22.8)$ \\
\hline Total & $162(100)$ \\
\hline \multicolumn{2}{|l|}{ Location } \\
\hline Rural & $107(66.0)$ \\
\hline Urban & $55(34.0)$ \\
\hline Total & $162(100)$ \\
\hline Subject & $116(71.6)$ \\
\hline Control & $46(28.4)$ \\
\hline Total & $162(100)$ \\
\hline \multicolumn{2}{|l|}{ Education Qualification } \\
\hline No formal education & $22(13.6)$ \\
\hline Primary education & $55(34.0)$ \\
\hline Secondary education & $85(52.4)$ \\
\hline Total & $162(100)$ \\
\hline
\end{tabular}


About one hundred and sixty two (162) subjects were involved in this study, out of which $107(66 \%)$ were residing in rural area while 55 (34\%) resided in urban areas. Of the 162 subjects, $59(36.4 \%)$ were males while $103(63.5 \%)$ were females. Test group (HIV-TB) with the age range of 31-40 years had the highest rate of HIV-TB co infection (61.7\%). The majorities of the test groups are Muslims, and accounted for $79.6 \%$ of the study population, while Christians accounted for $20.4 \%$ of the study population. Seventy $70(43.2 \%)$ were traders, $55(34.0 \%)$ were artisan, while the remaining 37 (22.8\%) were unemployed. Similarly, $85(52.5 \%)$ had secondary education, $55(34.0 \%)$ had primary education while $22(13.6 \%)$ had no formal education (Table 1).

Table 2: Platelet count, PT and APTT Parameters of test group (HIV-TB co-infected subjects) compared with control group

\begin{tabular}{lllll}
\hline Parameters & $\begin{array}{l}\text { Test group } \\
\mathbf{n}=\mathbf{1 1 6}\end{array}$ & $\begin{array}{l}\text { Control group } \\
\mathbf{n}=\mathbf{4 6}\end{array}$ & t value & P value \\
\hline PT & $17.74 \pm 2.08$ & $15.72 \pm 0.46$ & 6.535 & $0.000^{*}$ \\
PTTK & $76.72 \pm 18.01$ & $34.98 \pm 3.76$ & 15.561 & $0.000^{*}$ \\
PLATELET & $198.60 \pm 66.38$ & $221.04 \pm 125.99$ & 1.474 & 0.142 \\
\hline
\end{tabular}

*significant at $\mathrm{P}<0.05$

$\mathrm{PT}=$ Prothrombin time,

PTTK= Partial Thromboplastin Time with Koalin

The platelet count of the test group were with Koalin (APTTK) of HIV-TB co-infected significantly lower when compared with the control subjects were highly significant when compared group $(\mathrm{P}=0.142)$, However, the Prothrombin time (PT) and Activated Partial Thromboplastin Time with the control group $(\mathrm{P}<0.05)$ (Table 2$)$.

Table 3: Complete blood count parameters and $\mathrm{CD}_{4}$ cell count of HIV co-infected tuberculosis subjects and control

\begin{tabular}{lllll}
\hline Variable & Test group & Control group & t value & P value \\
\hline MCH(pg) & $26.19 \pm 3.09$ & $25.69 \pm 3.01$ & 0.931 & 0.353 \\
MCV(fl) & $80.21 \pm 7.74$ & $80.13 \pm 7.13$ & 0.056 & 0.955 \\
MCHC(g/l) & $30.87 \pm 2.83$ & $31.99 \pm 1.15$ & 3.567 & $0.000^{*}$ \\
RBC (X10\%/L) & $3.59 \pm 0.85$ & $4.62 \pm 0.44$ & 10.026 & $0.000^{*}$ \\
$\mathrm{Hb}(\mathrm{g} / \mathrm{L})$ & $9.29 \pm 1.57$ & $11.93 \pm 2.17$ & 7.521 & $0.000^{*}$ \\
$\mathrm{PCV}(\%)$ & $28.02 \pm 5.49$ & $37.20 \pm 6.20$ & 9.240 & $0.000^{*}$ \\
WBC (X10\%/L) & $437.14 \pm 975.18$ & $6771.74 \pm 1762.03$ & 8.715 & $0.000^{*}$ \\
Neutrophils (\%) & $49.49 \pm 16.63$ & $51.46 \pm 11.15$ & 0.868 & 0.387 \\
Lymphocytes (\%) & $36.97 \pm 14.23$ & $45.73 \pm 11.02$ & 4.183 & $0.000^{*}$ \\
Monocytes (\%) & $6.79 \pm 3.76$ & $9.00 \pm 0.79$ & 5.874 & $0.000^{*}$ \\
Eosinophils (\%) & $6.03 \pm 4.65$ & $4.13 \pm 2.32$ & 4.645 & $0.000^{*}$ \\
Basophils (\%) & $0.502 \pm 0.47$ & $0.13 \pm 0.22$ & 2.542 & $0.000^{*}$ \\
CD 4 COUNT & $228.23 \pm 144.24$ & $1120.63 \pm 367.06$ & 16.007 & $0.000^{*}$ \\
\hline
\end{tabular}

*significant at $\mathrm{P}<0.05$

$\mathrm{MCH}=$ Mean Corpuscular Haemoglobin

$\mathrm{RBC}=$ Red Blood Cell

$\mathrm{MCV}=$ Mean Corpuscular Volume

$\mathrm{Hb}=$ Haemoglobin

$\mathrm{WBC}=$ White Blood Cell

$\mathrm{MCHC}=$ Mean Corpuscular haemoglobin Concentration

$\mathrm{PCV}=$ Packed Cell Volume 
The haematological parameters studied include: Total white blood cell count (TWBC) $(\mathrm{P}<0.05)$, lymphocyte count $(\mathrm{P}<0.05)$, Monocyte count $(\mathrm{P}<0.05)$, Neutrophil count $(\mathrm{P}>0.05)$, Total red blood cell count $(\mathrm{P}<0.05)$, Mean Haemoglobin $(\mathrm{P}<0.05)$, Packed cell volume (PCV) $(\mathrm{P}<0.05)$, Mean cell volume $(\mathrm{P}>0.05)$, Mean Cell Haemoglobin $(\mathrm{P}>0.05)$, Mean cell haemoglobin concentration $(\mathrm{P}<0.05), \mathrm{CD}_{4}$ cell count $(\mathrm{P}<0.05)$ as seen in the table above. Most haematological parameters and $\mathrm{CD}_{4}$ cell count showed statistical significance when comparing the test group to the control group. However, neutrophil count, MCV, $\mathrm{MCH}$ did not show any statistical significance (Table 3).

Table 4: Haemostatic Parameters and platelet count of test group (HIV co-infected tuberculosis) based on their

\begin{tabular}{lllll}
\multicolumn{5}{c}{ location } \\
& Rural $(\mathbf{n}=\mathbf{6 1})$ & $\begin{array}{l}\text { Urban }(\mathbf{n}=\mathbf{5 5}) \\
\text { Mean } \pm \text { SD }\end{array}$ & T value & P value \\
\hline PT & $16.97 \pm 1.86$ & $18.60 \pm 1.98$ & 20.972 & $0.000^{*}$ \\
PTTK & $82.97 \pm 15.16$ & $69.80 \pm 18.50$ & 17.711 & $0.000^{*}$ \\
PLATELET & $156.77 \pm 58.43$ & $245.00 \pm 37.69$ & 91.150 & $0.000^{*}$
\end{tabular}

*significant at $\mathrm{P}<0.05$

$\mathrm{PT}=$ Prothrombin Time

PTTK=Partial Thromboplastin Time Kaolin

Platelet count was statistically raised in the urban population when compared to the rural population $(\mathrm{P}<0.05)$. However, the APTT of the

rural population significantly prolonged $(\mathrm{P}<0.05)$ when compared with the urban group (Table 4).

Table 5: Complete blood count parameters and $\mathrm{CD}_{4}$ cell count of test group (HIV co-infected with tuberculosis) among rural and urban settlers

\begin{tabular}{lllll}
\hline Variable & \multicolumn{1}{c}{ Rural } & \multicolumn{1}{c}{ Urban } & \multicolumn{1}{c}{ T value } & \multicolumn{1}{c}{ P value } \\
\hline MCH & $25.85 \pm 1.61$ & $26.58 \pm 4.15$ & 1.638 & 0.203 \\
MCV & $77.69 \pm 5.22$ & $83.00 \pm 9.06$ & 15.309 & $0.000^{*}$ \\
MCHC & $30.32 \pm 3.55$ & $31.48 \pm 1.55$ & 4.987 & $0.027^{*}$ \\
RBC & $3.60 \pm 1.00$ & $3.58 \pm 0,63$ & 0.013 & 0.908 \\
Hb & $9.24 \pm 1.24$ & $9.34 \pm 1.88$ & 0.118 & 0.732 \\
PCV & $26.35 \pm 4.68$ & $29.88 \pm 5.76$ & 13.221 & $0.000^{*}$ \\
WBC & $4440.98 \pm 1276.63$ & $4300.00 \pm 451.33$ & 0.602 & 0.439 \\
Neutrophil (\%) & $56.84 \pm 18.73$ & $41.36 \pm 8.46$ & 31.723 & $0.000^{*}$ \\
Lymphocyte (\%) & $32.38 \pm 16.16$ & $42.06 \pm 9.55$ & 15.014 & $0.000^{*}$ \\
Monocyte (\%) & $5.97 \pm 3.48$ & $7.72 \pm 3.86$ & 6.609 & $0.011^{*}$ \\
Eosinophils (\%) & $4.03 \pm 2.84$ & $8.24 \pm 5.25$ & 29.573 & $0.000^{*}$ \\
Basophil (\%) & $0.79 \pm 0.41$ & $0-.22 \pm 0.32$ & 67.932 & $0.000^{*}$ \\
CD & $204.09 \pm 126.03$ & $255.00 \pm 158.97$ & 3.686 & 0.057 \\
\hline
\end{tabular}

*significant at $\mathrm{P}<0.05$

$\mathrm{MCH}=$ Mean Corpuscular Haemoglobin

$\mathrm{RBC}=$ Red Blood Cell

$\mathrm{MCV}=$ Mean Corpuscular Volume

$\mathrm{PCV}=$ Packed Cell Volume

$\mathrm{Hb}=$ Haemoglobin

$\mathrm{MCHC}=$ Mean Corpuscular haemoglobin Concentration

Mean MCV $(\mathrm{P}<0.05)$ and mean MCHC $(\mathrm{P}=0.027)$ were observed to be statistically raised in urban settlers. PCV $(\mathrm{P}<0.05)$, lymphocyte count $(\%)$ $(\mathrm{P}<0.05)$, Monocyte count $(\%) \quad(\mathrm{P}=0.011)$ and Eosinophil count $\quad(\%) \quad(\mathrm{P}<0.05)$ were also significantly higher in urban settlers. However,
Basophil count $(\%)(\mathrm{P}<0.05)$ and Neutrophil count $(\%) \quad(\mathrm{P}<0.05)$ were significantly higher in rural settlers (Table 1.5). Mean $\mathrm{MCH}$, mean $\mathrm{RBC}$ count, mean haemoglobin, mean $\mathrm{WBC}$, and mean $\mathrm{CD}_{4}$ cell count showed significant variation in both populations (Table 5). 
Table 6: Gender comparison of Haematological Parameters among the test group $(n=116)$

\begin{tabular}{lrrrr}
\hline Variable & \multicolumn{1}{c}{ Male } & Female & T value & P value \\
\hline PT & $17.76 \pm 1.09$ & $17.73 \pm 2.54$ & 0.007 & 0.935 \\
PTTK & $64.11 \pm 5.95$ & $85.01 \pm 18.48$ & 54.970 & $0.000^{*}$ \\
PLATELET & $227.09 \pm 8.04$ & $179.89 \pm 80.03$ & 15.970 & $0.000^{*}$ \\
CD & $343.022 \pm 60.59$ & $152.80 \pm 133.13$ & 82.485 & $0.000^{*}$ \\
MCH & $27.70 \pm 3.48$ & $25.21 \pm 2.35$ & 21.185 & $0.000^{*}$ \\
MCV & $83.99 \pm 9.22$ & $77.72 \pm 5.35$ & 21.435 & $0.000^{*}$ \\
MCHC & $29.47 \pm 3.72$ & $31.79 \pm 1.47$ & 22.152 & $0.000^{*}$ \\
RBC & $4.36 \pm 0.87$ & $3.08 \pm 0.19$ & 141.216 & $0.000^{*}$ \\
Hb & $10.12 \pm 0.86$ & $8.74 \pm 1.69$ & 26.185 & $0.000^{*}$ \\
PCV & $34.24 \pm 0.86$ & $23.94 \pm 2.67$ & 637.298 & $0.000^{*}$ \\
WBC & $4595.65 \pm 157.71$ & $4228.57 \pm 1230.66$ & 4.037 & $0.047^{*}$ \\
Neutrophil & $36.95 \pm 11.14$ & $57.74 \pm 14.36$ & 69.008 & $0.000^{*}$ \\
Lymphocyte & $42.93 \pm 11.13$ & $33.05 \pm 14.75$ & 15.015 & $0.000^{*}$ \\
Monocyte & $8.27 \pm 4.16$ & $5.83 \pm 3.13$ & 12.999 & $0.000^{*}$ \\
Eosinophil & $10.89 \pm 3.08$ & $2.83 \pm 1.93$ & 30.369 & $0.000^{*}$ \\
Basophils & $0.47 \pm 0.46$ & $0.55 \pm 0.47$ & 0.686 & 0.409 \\
\hline
\end{tabular}

*significant at $\mathrm{P}<0.05$

$\mathrm{PT}=$ Prothrombin Time

$\mathrm{MCH}=$ Mean Corpuscular Haemoglobin

PTTK=Partial Thromboplastin Time Kaolin

$\mathrm{Hb}=$ Haemoglobin

$\mathrm{MCV}=$ Mean Corpuscular Volume

WBC $=$ White Blood Cell

$\mathrm{PCV}=$ Packed Cell Volume

$\mathrm{MCHC}=$ Mean Corpuscular haemoglobin Concentration

Mean PTTK, MCHC and Neutrophil count were significantly raised in females than in males $(\mathrm{P}<0.05)$. Whereas Mean Platelet count, $\mathrm{CD}_{4}$ cell count, $\mathrm{MCH}, \mathrm{PCV}, \mathrm{Hb}$ concentration, $\mathrm{RBC}$ count, $\mathrm{MCV}$, lymphocyte count, monocyte count and eosinophil were all significantly raised in male subjects $\quad(\mathrm{P}<0.05)$. Total WBC was also significantly higher in males than in females $(\mathrm{P}=0.047)$. However, there were no significant differences when comparing $\mathrm{PT}(\mathrm{P}=0.935)$ and Basophil count $(\mathrm{P}=0.409)$ of male and female subjects (Table 6).

\section{Discussion}

Tuberculosis and HIV co-infection has been reported in many studies and this has been a source of major concern in most parts of the developing world especially in Sub-Saharan Africa which houses $10 \%$ of the world population ${ }^{[29]}$. HIV complicates TB infection and is associated with a more rapid clinical decline. Infection with HIV increases the risk of reactivating latent $\mathrm{TB}$ infection, and $\mathrm{HIV}$-infected individuals who acquire new TB 
infections have high rates of disease progression ${ }^{[30}$, 29].

Lucas et al. ${ }^{[30]}$, reported that $30-40 \%$ death in HIV seropositive individuals is as results of tuberculosis co-infection. Sub-Saharan African has also been reported to have the highest tuberculosis incidence rate ${ }^{[30]}$. Similarly, WHO African region reported the highest incidence rate of tuberculosis and this was attributed to high incidence rate of HIV infection in the region [31]. Millet et al. [32] observed the association between tuberculosis incidence rate with poverty, overcrowding and malnutrition. Millet et al. ${ }^{[32]}$ reported that lowincome countries and deprived areas had a high tuberculosis HIV co-infection rate. The objective of this study was to assess some haematological parameters in subjects with HIV/TB co-infection and to evaluate the differences of the parameters in HIV/TB co-infected subjects living in rural and urban areas. Following the demographic information collected, this study showed that [31-40] years age range had the highest HIV/TB coinfection frequency. This is probably due to rate of incidence of HIV infection. Odiabo et al. [33] reported a similar result in this age group. However, a study by Awoyemi et al. ${ }^{[34]}$ reported that this age group had lowest prevalence rate of $23.3 \%$.

This study also observed that females were more infected than males, occupation of the subjects also had an impact on the frequency of HIV/TB coinfection, with traders having the highest frequency, and this may be due to migration from one town to the other during buying and selling. This study showed that subjects in the rural areas had the highest frequency rate when compared to subjects in the urban areas. This is mostly due to seroprevalence of HIV among low-income districts.

Anemia is an important hematological marker because it has been reported to be a significant independent risk factor for mortality in HIV-1infected patients. The high rate of anemia in Africa has been related to the levels of poverty, malnutrition, and the overall poor economic state [35]. In this study, when the test group was compared with the control group based on the indicator of anaemia, there was a significant reduction in PCV, $\mathrm{RBC}$ count and $\mathrm{Hb}$ concentration. The same observation was made when rural and urban areas were compared. This study observed a significant difference in the prevalence of anaemia among male and female subjects. Female subjects have a higher propensity to anaemia than males. Similarly, Camila and Parminder [36] observed a higher prevalence of anemia among women who are more liable to iron deficiency anaemia. However, DeSantis et al. ${ }^{[37]}$ did not observe any difference in the prevalence of anemia among women and men who were co-infected with TB and HIV. This study observed a higher proportion of microcytic anemia in female subjects, as seen in the RBC indices values, which were significantly lower in females. This could perhaps be explained by a higher propensity of this group of subjects to have iron deficiency due to female monthly menstrual flow.

Endothelial damage has been associated with HIV and TB infections and endothelial dysfunction has been associated with coagulation defects ${ }^{[38]}$. Therefore it is expected that HIV subjects coinfected with TB should be monitored for coagulation abnormalities.

The PT and PTTK results among HIV/TB coinfected subjects were significantly raised $(\mathrm{P}<0.05)$, the platelet count was not significantly raised. This is probably due to endothelial damage, which results in activation of the coagulation factors and subsequent consumption of the factors. It has also been reported that anticardiolipin antibodies and lupus anticoagulants seen in HIV patients can affect PT and APTT ${ }^{[39]}$. Baker et al. ${ }^{[40]}$ reported that tissue factor (TF) released by sub-endothelial cells during vascular damage, binds to circulating factor VII with formation of VIIa. The TF: VIIa complex activate factor $\mathrm{X}$ to factor $\mathrm{Xa}$ and this proceeds through the usual coagulation cascade. This indicates that endothelial activation is mainly responsible for the prolonged PT and APTT and the relatively non-significant changes in platelet count observed in this study. Similarly, Omoregie et al. ${ }^{[41]}$ reached a similar agreement when they were observing the relationship between PT, PTTK and $\mathrm{CD}_{4}$ cell count in HIV patients in Benin City. This study observed a statistical significant increase in PTTK among rural settlers when compared to urban settlers. This study observed a direct correlation between Total white cell count and $\mathrm{CD}_{4}$ cell count. This was probably due to the fact that $\mathrm{CD}_{4}$ cells are from the leucocyte lineage. The study showed a significant reduction in $\mathrm{CD}_{4}$ count in $\mathrm{HIV} / \mathrm{TB}$ co- 
infected subject when compared with controls $(\mathrm{P}<0.05)$. The HIV attacks and destroys cells with the $\mathrm{CD}_{4}$ antigen and this explains why HIV positive patients had lower $\mathrm{CD}_{4}$ counts than HIV-negative control group. Additionally, HIV increases the risk of TB infection and disease progression and TB slows down $\mathrm{CD}_{4}$ cell recovery and increases the progression of HIV to AIDS [42]. Like the $\mathrm{CD}_{4}$ count, the platelet count was lower in HIV/TB co-infected subjects $(\mathrm{P}<0.05)$. Impaired thrombopoiesis and production of antiplatelet antibodies have been suggested as possible mechanisms ${ }^{[39]}$. Impaired thrombopoiesis can result from infection of megakaryocytes by HIV because megakaryocytes possess $\mathrm{CD}_{4}$ and $\mathrm{CXCR} 4$, which are known receptors for HIV ${ }^{[43]}$. Similarly, Nwankwo et al. ${ }^{[44]}$ also reported stickiness of platelets in TB patients monitored in Kano metropolis. Omoregie et al. [40] observed a reduced platelet count in patients who had a $<200$ cells $/ \mu \mathrm{L} \mathrm{CD}_{4}$ count. Platelet count of urban settler was significantly elevated $(\mathrm{P}<0.05)$ when compared with the rural settlers. Male subjects also had a significant increase in platelets count.

\section{Conclusion}

$\mathrm{TB}$ is an aggressive opportunistic infection, and TB co-infection with HIV will only increase the mortality rate in the patients.

\section{References}

1 AIDS Control and Prevention (AIDSCAP). Project of Family Health Internal, The Francois-Xavier Bagnoud Center for Public Health and Human Rights Of the Harvard School of Public Health, UNAIDS. The Status and Trends of the Global HIV/AIDS Pandemic, 1996.

2 Raviglione, MC.;Snider, DE.; Kochi, A. Global epidemiology of tuberculosis: morbidity and mortality of a worldwide epidemic. Journal of America Medical Association. 1995; 273: 220226 DOI:10.1001/jama.1995.03520270054031

3 Selwyn PA, Hartel D, Lewis VA, Schoenbaum EE, Vermund SH, Klein RS, Walker AT, Friedland GH. A prospective study of the risk of tuberculosis among intravenous drug users with human immunodeficiency virus infection. N Engl J Med 1989; 320(9): 545-550 [PMID: 2915665 DOI: 10.1056/NEJM198903023200901]

4 Daley, CL.;Small, PM.; Schecter, GF.; et al. An outbreak of tuberculosis with accelerated progression among persons infected with the human immunodeficiency virus. An analysis using restriction-fragment-length polymorphisms. New England Journal of Medicine. 1992; 326(4):231-235 DOI: https://doi.org/10.1016/0196-6553(93)90039-7

5 Small PM, Hopewell PC, Singh SP, Paz A, Parsonnet J, Ruston DC, Schecter GF, Daley CL, Schoolnik GK. The epidemiology of tuberculosis in San Francisco. A populationbased study using conventional and molecular methods. N Engl J Med 1994; 330(24): 17031709 DOI: 10.1056/NEJM199406163302402

6 Newport MJ, Huxley CM, Huston S, Hawrylowicz CM, Oostra BA, Williamson R, Levin M. A mutation in the interferon-gammareceptor gene and susceptibility to mycobacterial infection. N Engl J Med 1996; 335(26): 1941-1949 [PMID: 8960473 DOI: 10.1056/NEJM199612263352602]

7 Barnes PF, Modlin RL. Human cellular immune responses to Mycobacterium tuberculosis. Curr Top Microbiol Immunol 1996; 215: 197-219 [PMID: 8791715 DOI: 10.1007/978-3-642-80166-2_9]

8 Kumar, V.Robbins and Cotran Pathologic Basis of Disease. Elsevier Saunders. 9th edition. 2010; Pp. 659-720.

9 Cossarizza A, Ortolani C, Mussini C, Borghi V, Guaraldi G, Mongiardo N, Bellesia E, Franceschini MG, De Rienzo B, Franceschi C. Massive activation of immune cells with an intact $\mathrm{T}$ cell repertoire in acute human immunodeficiency virus syndrome. J Infect Dis 1995; 172(1): 105-112 [PMID: 7797898 DOI: 10.1093/infdis/172.1.105]

10 Calder PC. Immunological parameters: what do they mean? $\boldsymbol{J}$ Nutr 2007; 137(3 Suppl 2): 773S-780S DOI: $\underline{10.1093 / \mathrm{jn} / 137.3 .773 \mathrm{~S}}$

11 Awodu OA, Ajayi IO, Famodu AA. Haemorheological variables in Nigeria pulmonary tuberculosis patients undergoing 
therapy. Clin Hemorheol Microcirc 2007; 36(4): 267-275 [PMID: 17502697]

12 Das BS, Devi U, Mohan Rao C, Srivastava VK, Rath PK, Das BS. Effect of iron supplementation on mild to moderate anaemia in pulmonary tuberculosis. $\boldsymbol{B r} \boldsymbol{J}$ Nutr 2003; 90(3): 541-550 DOI: $10.1079 /$ bjn2003936

13 Behler C, Shade S, Gregory K, Abrams D, Volberding P. Anemia and HIV in the antiretroviral era: potential significance of testosterone. AIDS Res Hum Retroviruses 2005; 21(3): 200-206 [PMID: 15795525 DOI: 10.1089/aid.2005.21.200]

14 Fauci AS. Multifactorial nature of human immunodeficiency virus disease: implications for therapy. Science 1993; 262(5136): 10111018 DOI: $10.1126 /$ science. 8235617

15 Sierra S, Kupfer B, Kaiser R. Basics of the virology of HIV-1 and its replication. J Clin Virol 2005; 34(4): 233-244 [PMID: 16198625 DOI: $10.1016 / j . j e v .2005 .09 .004]$

16 Sundquist WI, Krausslich HG. HIV-1 assembly, budding, and maturation. Cold Spring Harb Perspect Med 2012; 2(7): a006924 DOI: $10.1101 /$ cshperspect.a006924

17 Gomez C, Hope TJ. The ins and outs of HIV replication. Cell Microbiol 2005; 7(5): 621626 DOI: 10.1111/j.1462-5822.2005.00516.x

18 De-Wolf, F.; Lange, JMA. Serologic and Immunologic Markers in the Course of HIV-1 Infection. Clinics in Dermatology. 1991; 9: 111.

19 Zon LI, Arkin C, Groopman JE. Haematologic manifestations of the human immune deficiency virus (HIV). Br J Haematol 1987; 66(2): 251-256 DOI: $10.1111 / \mathrm{j} .1365-$ 2141.1987.tb01307.x

20 Basu,A;Ghosh, K.; Banerjee, K.Bone marrow involvement in HIV infection: light, electron and immuno electron microscopic studies. Indian Journal of Hematology and Blood Transfusion. 1999; 17(4): 76-86.

21 Gange SJ, Lau B, Phair J, Riddler SA, Detels R, Margolick JB. Rapid declines in total lymphocyte count and hemoglobin in HIV infection begin at $\mathrm{CD}_{4}$ lymphocyte counts that justify antiretroviral therapy. AIDS 2003; 17(1): 119-121 DOI: $10.1097 / 00002030-$ $\underline{\text { 200301030-00016 }}$
22 Muluneh, A.; Fessahaye, A. Hematologic abnormalities among children on HAART in Jimma University Specialized Hospital, Southwestern Ethiopia. Ethiopian Journal of Health Science. 2009; 14(2): 83-89.

23 Alavi-Naini R, Moghtaderi A, Metanat M, Mohammadi M, Zabetian M. Factors associated with mortality in tuberculosis patients. J Res Med Sci 2013; 18(1): 52-55 [PMID: 23901338 PMCID: PMC3719227]

24 Isanaka S, Mugusi F, Urassa W, Willett WC, Bosch RJ, Villamor E, Spiegelman D, Duggan $\mathrm{C}$, Fawzi WW. Iron deficiency and anemia predict mortality in patients with tuberculosis. $\boldsymbol{J}$ Nutr 2012; 142(2): 350-357 DOI: 10.3945/jn.111.144287

25 Kisich KO, Higgins M, Diamond G, Heifets L. Tumor necrosis factor alpha stimulates killing of Mycobacterium tuberculosis by human neutrophils. Infect Immun 2002; 70(8): 45914599 DOI: $10.1128 /$ iai.70.8.4591-4599.2002

26 Baynes RD, Bothwell TH, Flax H, McDonald $\mathrm{TP}$, Atkinson P, Chetty N, Bezwoda WR, Mendelow BV. Reactive thrombocytosis in pulmonary tuberculosis. J Clin Pathol 1987; 40(6): 676-679 DOI: $10.1136 / j \mathrm{jc} .40 .6 .676$

27 NACA. Nigerian HIV prevalence rate. www.naca.gov.ng/nigeria.accessed 15-10-2016

28 Dean GL, Edwards SG, Ives NJ, Matthews G, Fox EF, Navaratne L, Fisher M, Taylor GP, Miller R, Taylor CB, de Ruiter A, Pozniak AL. Treatment of tuberculosis in HIV-infected persons in the era of highly active antiretroviral therapy. AIDS 2002; 16(1): 7583 DOI: $10.1097 / 00002030-200201040-00010$

29 Mukadi YD, Maher D, Harries A. Tuberculosis case fatality rates in high HIV prevalence populations in sub-Saharan Africa. AIDS 2001; 15(2): 143-152 DOI: $\underline{10.1097 / 00002030-}$ 200101260-00002

30 Lucas SB, Hounnou A, Peacock C, Beaumel A, Djomand G, N'Gbichi JM, Yeboue K, Honde $\mathrm{M}$, Diomande $\mathrm{M}$, Giordano $\mathrm{C}$, et al. The mortality and pathology of HIV infection in a west African city. AIDS 1993; 7(12): 15691579 DOI: $10.1097 / 00002030-199312000-$ 00005

31 Corbett EL, Watt CJ, Walker N, Maher D, Williams BG, Raviglione MC, Dye C. The 
growing burden of tuberculosis: global trends and interactions with the HIV epidemic. Arch Intern Med 2003; 163(9): 1009-1021 [PMID: 12742798 DOI: 10.1001/archinte.163.9.1009]

32 Millet JP, Moreno A, Fina L, del Bano L, Orcau A, de Olalla PG, Cayla JA. Factors that influence current tuberculosis epidemiology. Eur Spine J 2013; 22 Suppl 4: 539-548 DOI: 10.1007/s00586-012-2334-8

33 Odiabo,GN.;Okonkwo,P.;Lawal, OM.; Olaleye, DO. HIV infection among newly diagnosed TB patients in Southwestern Nigeria. African Journal of Medicine and Medical Sciences. 2013; 3: 154-159 DOI: $10.4236 /$ wja.2013.32020

34 Awoyemi OB, Ige OM, Onadeko BO. Prevalence of active pulmonary tuberculosis in human immunodeficiency virus seropositive adult patients in University College Hospital, Ibadan, Nigeria. Afr J Med Med Sci 2002; 31(4): 329-332 [PMID: 15027773]

35 Firnhaber C, Smeaton L, Saukila N, Flanigan T, Gangakhedkar R, Kumwenda J, La Rosa A, Kumarasamy N, De Gruttola V, Hakim JG, Campbell TB. Comparisons of anemia, thrombocytopenia, and neutropenia at initiation of HIV antiretroviral therapy in Africa, Asia, and the Americas. Int J Infect Dis 2010; 14(12): e1088-1092 DOI: 10.1016/j.ijid.2010.08.002

36 Chaparro CM, Suchdev PS. Anemia epidemiology, pathophysiology, and etiology in low- and middle-income countries. $\operatorname{Ann} \mathbf{N} \boldsymbol{Y}$ Acad Sci 2019; 1450(1): 15-31 DOI: $\underline{10.1111 / \text { nyas. } 14092}$

37 De Santis GC, Brunetta DM, Vilar FC, Brandao RA, de Albernaz Muniz RZ, de Lima GM, Amorelli-Chacel ME, Covas DT, Machado AA. Hematological abnormalities in HIV-infected patients. Int J Infect Dis 2011; 15(12): e808-811 [PMID: 21880530 DOI: $\underline{\text { 10.1016/j.ijid.2011.08.001] }}$
38 Andrade AC, Cotter BR. Endothelial function and cardiovascular diseases in HIV infected patient. Braz J Infect Dis 2006; 10(2): 139145 DOI: $10.1590 / \mathrm{s} 1413-86702006000200012$

39 Karpatkin, S.; Nardi, M.; Green, D. Platelet and Coagulation Defects Associated with HIV-1Infection. Thrombosis and Haemostasis. 2002; 88: 389-401 PMID: 12353066 DOI: $10.1055 / \mathrm{s}-$ 0037-1613228

40 Baker, FJ.; Silverton, RE.; Pallister, CJ. Baker and Silverton's Introduction to Medical Laboratory Science Technology (7th Ed) Butterworth-Heinemann, Oxford, England. 1998; Pp. 344-386.

41 Omoregie R, Osakue SI, Ihemeje V, Omokaro EU, Ogeferet HO. Correlation of $\mathrm{CD}_{4}$ count with platelet count, prothrombin time and activated partial thromboplastin time among HIV patients in Benin City, Nigeria. West Indian Med J 2009; 58(5): 437-440 [PMID: 20441062]

42 Torhein, JA.; Dooley, KE. Tuberculosis associated with HIV infection. Microbiology Spectrum. 2017; 5(1): 123-137 DOI:101128/microbiolspec.TNM17-00282016

43 Sakaguchi, M.; Sato, T.; Groopman, J. Immunodeficiency virus infection of megakaryocytic cells. Blood. 1991; 77: 481 DOI: $\underline{10.1182 / \text { blood.V77.3.481.481 }}$

44 Nwankwo, EK.; Kwaru, A.; Ofulu, A.; Babashanim, F. Haematological changes in tuberculosis in Kano, Nigeria. Journal of Medical Laboratory Science. 2005; 14(2): 35-39 DOI: $10.4314 /$ jmls.v14i2.35326 